\title{
Rotational Grazing on Rangelands: Reconciliation of Perception and Experimental Evidence
}

\author{
D. D. Briske, ${ }^{1}$ J. D. Derner, ${ }^{2}$ J. R. Brown, ${ }^{3}$ S. D. Fublendorf, ${ }^{4}$ W. R. Teague, ${ }^{5}$ K. M. Havstad, ${ }^{6}$ \\ R. L. Gillen, ${ }^{7}$ A. J. Ash, ${ }^{8}$ and W. D. Willms ${ }^{9}$
}

Authors are ${ }^{1}$ Professor, Department of Ecosystem Science and Management, Texas A $\mho M$ University, College Station, TX 77843-2138, USA; ${ }^{2}$ angeland Scientist, USDA-ARS High Plains Grasslands Research Station, Cheyenne, WY 82009, USA; ${ }^{3}$ Research Scientist, USDA-NRCS Jornada Experimental

Range, New Mexico State University, Las Cruces, NM 88003-0003, USA; ${ }^{4}$ Professor, Department of Natural Resource Ecology and Management, Oklahoma State University, Stillwater, OK 74078, USA; ${ }^{5}$ Professor, Texas A\&M University System, Texas Agricultural Experiment Station, Vernon, TX 76384, USA; ${ }^{6}$ Supervisory Scientist, USDA-ARS Jornada Experimental Range, New Mexico State University, Las Cruces, NM 88003-0003, USA; ${ }^{7}$ Head, Kansas State University, Western Kansas Agricultural Research Centers, Hays, KS 67601-9228, USA; ${ }^{8}$ Program Leader, CSIRO, Sustainable Ecosystems, St. Lucia, Queensland 4067, Australia; and ${ }^{9}$ Research Scientist, Agriculture and Agri-Food Canada, Lethbridge, AB T1J 4B1, Canada.

\begin{abstract}
In spite of overwhelming experimental evidence to the contrary, rotational grazing continues to be promoted and implemented as the only viable grazing strategy. The goals of this synthesis are to 1) reevaluate the complexity, underlying assumptions, and ecological processes of grazed ecosystems, 2) summarize plant and animal production responses to rotational and continuous grazing, 3) characterize the prevailing perceptions influencing the assessment of rotational and continuous grazing, and 4) attempt to direct the profession toward a reconciliation of perceptions advocating support for rotational grazing systems with that of the experimental evidence. The ecological relationships of grazing systems have been reasonably well resolved, at the scales investigated, and a continuation of costly grazing experiments adhering to conventional research protocols will yield little additional information. Plant production was equal or greater in continuous compared to rotational grazing in $87 \%$ (20 of 23) of the experiments. Similarly, animal production per head and per area were equal or greater in continuous compared to rotational grazing in $92 \%$ (35 of 38 ) and $84 \%$ (27 of 32) of the experiments, respectively. These experimental data demonstrate that a set of potentially effective grazing strategies exist, none of which have unique properties that set one apart from the other in terms of ecological effectiveness. The performance of rangeland grazing strategies are similarly constrained by several ecological variables establishing that differences among them are dependent on the effectiveness of management models, rather than the occurrence of unique ecological phenomena. Continued advocacy for rotational grazing as a superior strategy of grazing on rangelands is founded on perception and anecdotal interpretations, rather than an objective assessment of the vast experimental evidence. We recommend that these evidence-based conclusions be explicitly incorporated into management and policy decisions addressing this predominant land use on rangelands.
\end{abstract}

\section{Resumen}

A pesar de la abrumadora evidencia experimental en contra, el apacentamiento rotacional continua siendo promovido e implementado como la única estrategia viable de apacentamiento. Las metas de esta síntesis son para: 1) reevaluar la complejidad, los supuestos fundamentales, y los procesos ecológicos de los ecosistemas apacentados, 2) resumir las respuestas de producción vegetal y animal al apacentamiento rotacional y continuo, 3) caracterizar las percepciones prevalecientes que influyen en la evaluación del apacentamiento rotacional y continuo, 4) intentar dirigir la profesión hacia una reconciliación de las percepciones que abogan por apoyo para los sistemas rotacionales de apacentamiento con las de la evidencia experimental. Las relaciones ecológicas de los sistemas de apacentamiento han sido razonablemente bien resueltas, a las escalas investigadas, y una continuación de experimentos costosos de apacentamientos, adheridos a los protocolos convencionales, producirán poca información adicional. La producción vegetal fue igual o mayor en el apacentamiento continuo en comparación con el rotacional en $87 \%$ ( 20 de 23$)$ de los experimentos. Similarmente, la producción animal por cabeza y por área fueron iguales o mayores en el apacentamiento continuo en comparación con el rotacional en el $92 \%$ ( 35 de 38 ) y $84 \%$ (27 de 32) de los experimentos, respectivamente. Estos datos experimentales demuestran que existe un grupo de estrategias de apacentamiento potencialmente efectivas, ninguna de las cuales tiene propiedades únicas que separen una de las otras en términos de efectividad ecológica. El comportamiento de las estrategias de apacentamiento del pastizal están limitadas en forma similar por varias variables ecológicas, que establecen que las diferencias entre ellas son dependientes de la efectividad de los modelos de manejo, mas que de la ocurrencia de un fenómeno ecológico único. El continuo abogar por el apacentamiento rotacional como estrategia superior de apacentamiento de los pastizales esta fundado en la percepción de interpretaciones anecdóticas mas que en una evaluación objetiva de la vasta evidencia experimental. Recomendamos que estas

This manuscript emerged from a symposium organized by W. D. Willms entitled "Effectiveness of Grazing Systems on Rangelands: A Critical Examination of the Evidence" held at the 59th Annual Meeting of the Society for Range Management, Vancouver, British Columbia, Canada, 12-17 February 2006.

The review process and final acceptance for this paper was conducted by the previous Editor-in-Chief, M. K. Owens

Correspondence: D. D. Briske, Dept of Ecosystem Science and Management, TAMU 2138, Texas A\&M University, College Station, TX 77843-2138, USA. Email: dbriske@tamu.edu

Manuscript received 25 November 2006; manuscript accepted 15 September 2007. 
conclusiones basadas en evidencia sean incorporadas explícitamente en el manejo y las políticas de decisión que abordan este uso predominante de los pastizales.

Key Words: continuous grazing, domestic herbivores, grazed ecosystems, grazing management, grazing systems, rangeland management

\section{INTRODUCTION: THE DILEMMA OF GRAZING SYSTEMS}

The principle of rotational grazing was described by James Anderson near the end of the 18th century in Scotland (Voisin 1959), but implementation of rotational grazing systems on rangelands is a relatively recent phenomenon. Grazing systems progressed during the 20th century from simple deferred systems (Sampson 1913), to more sophisticated rotational systems (Merrill 1954; Hormay and Evanko 1958; Vallentine 1967; Tainton et al. 1999), and most recently to intensive short duration systems (Savory 1978, 1983, 1988; Savory and Parsons 1980). The general goal of grazing systems was to increase production by ensuring that key plant species captured sufficient resources (e.g., light, water, nutrients) to enhance growth and by enabling livestock to harvest available forage more efficiently. The specific objectives by which grazing systems were purported to increase production were to 1) improve species composition or productivity by ensuring key plant species a rest period during the growing season, 2) reduce animal selectivity by increasing stock density (i.e., animals per land unit) to overcome small-scale heterogeneity (i.e., patch grazing), and 3) ensure more uniform animal distribution within large heterogeneous management units by improving water distribution and/or cross-fencing. We subscribe to a broad definition of grazing systems as a specialization of grazing management that defines reoccurring periods of grazing, rest, and deferment for two or more pastures (Heitschmidt and Taylor 1991). The basic types of rotational grazing systems are described in Table 1.

The preponderance of evidence generated from grazing experiments over the past 60 years has consistently indicated that rotational grazing is not superior to continuous grazing on rangelands (Table 2). This was true for the initial grazing experiments (Sampson 1951; Heady 1961), numerous investigations conducted throughout the 1970-1980s (O'Reagain and Turner 1992; Holechek et al. 2001; Norton 2003), and several rigorously designed recent investigations (Hart et al. 1993a, 1993b; Manley et al. 1997; Gillen et al. 1998; McCollum et al. 1999; Derner and Hart 2007). Yet, in spite of clear and consistent experimental evidence demonstrating that rotational grazing and continuous grazing have similar effectiveness on rangelands, rotational grazing continues to be promoted and implemented as a superior grazing system (Norton 1998, 2003; Tainton et al. 1999; Teague et al. 2004). Strong perceptions must exist to maintain advocacy for rotational grazing systems over continuous grazing in the presence of overwhelming experimental evidence to the contrary. Heady (1961) observed that the perceived benefits of rotational grazing developed early in the profession when researchers offered explanations as to why their results failed to support rotational grazing systems, rather than directly concluding that there were no differences between rotational and continuous grazing.

The specific objectives of this synthesis are to 1) reevaluate the complexity, underlying assumptions, and ecological processes governing the response of grazed ecosystems, 2) summarize plant and animal production responses to rotational and continuous grazing, 3) characterize the prevailing perceptions influencing the assessment of rotational and continuous grazing, and 4) attempt to direct the profession toward a reconciliation of perceptions advocating support for rotational grazing systems with that of the experimental evidence. This assessment is specific to the application of commercial grazing operations, and it does not explicitly consider grazing dynamics associated with herding, migratory grazing, or transhumance.

\section{PRIMARY SOURCES OF COMPLEXITY AND CONFUSION}

The absence of consistent management and policy recommendations concerning the adoption of grazing systems after several decades of experimental research and commercial application is a testament to the complexity of this task. The complexity resides in the broad array of confounding variables that make a direct, valid comparison between grazing systems and continuous grazing all but impossible (Heady 1961). Consider the wide range of ecological variation associated with rainfall regime (i.e., amount, seasonality, and intra- and interannual variability), vegetation structure, composition, productivity, prior land use, and livestock characteristics (i.e., breeds, prior conditioning, care, and handling). This tremendous ecological variability is paralleled by variability associated with the commitment, ability, goals (i.e., production vs. conservation), and opportunities (i.e., land ownership, alterna-

Table 1. Characteristics of basic rotational grazing systems implemented on rangelands.

\begin{tabular}{|c|c|c|c|c|c|}
\hline Grazing system & Stock density & No. of herds & Length of grazing & Length of rest & Tactic \\
\hline Deferred rotation & Moderate & Single & Long & Moderate & $\mathrm{HPG}^{1}$ \\
\hline Rest rotation & Moderate & Multiple & Long & Short & $H U G^{2}$ \\
\hline Rest rotation & High & Single & Short & Long & $\mathrm{HPG}$ \\
\hline High intensity-low frequency & High & Single & Moderate & Long & HUG \\
\hline Short duration & High & Single & Short & Moderate & $H P G$ \\
\hline
\end{tabular}

${ }^{1}$ High-performance grazing strategy that enables selective grazing of preferred plants.

${ }^{2}$ High-utilization grazing strategy that affects heavy utilization of both preferred and nonpreferred plants (adapted from Heitschmidt and Taylor 1991). 
Table 2. Conclusions from major reviews of grazing systems research spanning the last 50 years of the rangeland profession. Experimental data have consistently indicated that rotational grazing is not superior to continuous grazing on rangelands.

\begin{tabular}{ll}
\hline \multicolumn{1}{c}{ Review citation } & Quotation of conclusions \\
\hline Sampson (1951, p. 21) & $\begin{array}{c}\text { "two fairly distinct viewpoints [exist] among range conservationists and operators regarding the merits of rotation or } \\
\text { deferred-rotation grazing." } \\
\text { "specialized grazing system has no advantage in livestock production over continuous grazing, at least with good or excellent } \\
\text { ranges under comparable stocking rates and degree of care in other management practices; ... other management factors } \\
\text { are more important in the production of livestock than system of grazing." }\end{array}$ \\
$\begin{array}{l}\text { "lan Poollen and Lacey (1979, p. 253) } \\
\text { "land mangers should place more emphasis on proper stocking intensity, and less on grazing system implementation." } \\
\text { "stocking rate is a major determinant of both range condition and animal production, and is possibly the most important } \\
\text { management variable under the direct control of the grazer. Relative to this variable, the grazing system employed is of } \\
\text { minor importance, with there being little apparent difference between continuous and rotational grazing systems." }\end{array}$ \\
\hline
\end{tabular}

tive revenue sources) of managers operating these systems. Managerial variability poses a unique problem because, unlike ecological variability, it is seldom recognized and documented, which makes it especially difficult to disentangle from the ecological component of grazing systems. In spite of this tremendous variability, stocking rate has emerged as the most consistent management variable influencing both plant and animal responses to grazing (e.g., Heady 1961; O'Reagain and Turner 1992; Ash and Stafford Smith 1996; Holechek et al. 2001).

To emphasize the importance of management as a confounding variable, consider that a well-managed rotational system will very likely achieve desired production goals more effectively than poorly managed continuous grazing. A visual inspection could lead to the conclusion that rotational grazing is more beneficial than continuous grazing, but this is not a legitimate comparison of these two grazing regimes because it is confounded by tremendous managerial variability. In other words, the reverse is also true that well-managed continuous grazing would be more effective than poorly managed rotational grazing. It has often been suggested, but not documented, that intensive grazing systems require more sophisticated management than do more simple systems. This intuitively leads us to conclude that management commitment and ability are the most pivotal components of grazing system effectiveness and that grazing systems do not possess unique properties that enable them to compensate for ineffective management (i.e., grazing systems do not provide a "silver bullet" to ensure attainment of desired goals).

\section{UNIFIED VEGETATION RESPONSES TO GRAZING}

Several unifying principles of vegetation response to grazing have emerged from the rangeland literature during the past century. These principles constitute well-recognized and widely applied management rules of thumb that are founded on well-substantiated ecological mechanisms. These principles are briefly summarized here because they shape our perception of the purported benefits of grazing systems. These principles include the following:

1) Chronic, intensive grazing is detrimental to plant growth and survival;
2) Primary productivity can be increased by lenient grazing and decreased by severe grazing;

3) Forage quality is often improved by frequent grazing; and

4) Species composition of plant communities can be modified in response to the frequency, intensity, and seasonality of grazing.

\section{Chronic, Intensive Grazing}

Chronic, intensive grazing is detrimental to plants because it removes leaf area that is necessary to absorb photosynthetically active radiation and convert it to chemical energy (Caldwell et al. 1981; Briske and Richards 1995). This reduction in energy harvest is manifest in all aspects of plant growth and function because photosynthesis provides the total energy and carbon source for growth. A chronic, intensive reduction in photosynthetic leaf area negatively impacts root systems by reducing energy available to support existing root biomass and new root production. Root mass, branch number, vertical and horizontal root distribution, and root longevity all may be reduced by chronic, intensive defoliation (Hodgkinson and Bass Becking 1977). This reduces the ability of severely grazed plants to effectively access soil water and nutrients that often limit plant growth on rangelands.

Rest and deferment is the antithesis of this principle, which indicates that periodic cessation of grazing, especially during periods of rapid growth, will enhance both shoot and root growth by promoting the recovery and maintenance of greater leaf area (Holechek et al. 2001). Rest and deferment to promote plant growth is the most fundamental and longstanding corollary of the unifying principles and it represents a central assumption of all grazing systems.

\section{Primary Productivity}

Grazing was assumed to have a negative effect on primary production throughout much of the history of the rangeland profession for reasons described in the previous section. Therefore, an important goal of early range management was to implement grazing in a way that would minimize negative effects on both plant production and species composition. The potential for grazing to increase plant production was not considered a viable option (Ellison 1960) until the 1970s when ecologists introduced the grazing optimization hypothesis. This hypothesis indicates that primary production increases above that of ungrazed vegetation as grazing intensity increases to an 
optimal level followed by a decrease at greater grazing intensities (McNaughton 1979). Evidence exists to support the occurrence of the grazing optimization hypothesis at both the plant and community levels (Belsky 1986; Milchunas and Lauenroth 1993), and several potential mechanisms have been hypothesized and tested (McNaughton 1983).

However, grazing increased primary production in only approximately $20 \%$ of the comparisons evaluated (Belsky 1986; Milchunas and Lauenroth 1993). Presumably grazing was too intensive to promote compensatory growth, and this is often the case in commercial grazing systems (McNaughton 1993). The grazing pattern required to increase primary production has been compared to that of migratory herbivores because it is associated with a period of intensive grazing, often early in the season, followed by a long period of little or no grazing (Frank and McNaughton 1993). As a result, an absolute increase in plant growth is seldom documented in grazing ecosystems because plants do not have a sufficient opportunity for recovery following defoliation, and primary production generally decreases with increasing grazing severity compared to that of ungrazed communities (Milchunas and Lauenroth 1993).

\section{Forage Quality}

Forage quality determines the amount of energy and nutrients that herbivores can acquire from ingested forage, and it varies with several well-recognized plant characteristics. Tissue age, tissue type, functional plant group, and anti-quality agents (e.g., lignin, cellulose, secondary compounds) represent several of the more widely recognized characteristics (Van Soest 1982; Huston and Pinchak 1991). These characteristics primarily affect forage quality by influencing the ratio of cell soluble (e.g., amino acids, proteins, lipids, starch) to cell structural (e.g., hemicellulose, cellulose, lignin, silica) components within plant tissues. Tissues with the highest soluble to structural ratio typically possess the highest forage quality and are often the most preferred by grazing animals. Secondary compounds function as anti-quality agents to reduce forage quality of both herbaceous and woody dicots, but are generally less important in deterring herbivory in monocots (McNaughton 1983; Vicari and Bazely 1993). The ratio of soluble to structural cellular components decreases as mean tissue age increases throughout the growing season. Frequent grazing reduces this tendency by increasing the proportion of younger plant tissues with higher soluble to structural ratios (Walker et al. 1989; Georgiadis and McNaughton 1990). This explains the frequent occurrence of patch grazing where animals repeatedly graze the same area to optimize energy and nutrient intake per unit plant biomass even though total biomass may be substantially lower than in less frequently grazed patches (McNaughton 1984).

Forage quality is an important consideration in the design and implementation of grazing systems, and it is influenced by the length of both the grazing and the rest periods between subsequent grazing events. Animal performance declined linearly with increasing length of grazing period and length of rest period in a rotational grazing study in South African rangeland (Denny and Barnes 1977). A long rest period or a low grazing pressure allows plant tissues to mature and forage quality to decrease compared to more frequent grazing intervals.

\section{Community Composition}

Grazing induced modification of species composition originates from the species-specific reduction of leaf area and whole plant photosynthesis previously discussed (Briske and Richards 1995; Illius and O’Connor 1999). Selective grazing of individual species or species groups places them at a competitive disadvantage with less severely grazed species or species groups and alters competitive interactions and species composition within communities (Anderson and Briske 1995). The first quantitative procedure to evaluate the effect of grazing on community composition was based on recognition that selective grazing disproportionately affects some plant groups more than others. Dyksterhuis (1949) formally introduced the concept of increaser, decreaser, and invader plant response groups, but specific patterns of vegetation response to grazing had been recognized by many of his predecessors, including Arthur Sampson (Sampson 1919). These response groups are a function of a plant's ability to avoid or tolerate grazing. These plant response groups are based on the expression of numerous plant traits, but plant height and meristem location and number appear to be among the most important. For example, plant height during various stages of phenological development influences both the frequency and intensity of defoliation, and the corresponding location and number of remaining meristems determine the rate at which leaf area is replaced (Briske and Richards 1995; Díaz et al. 2001).

Community composition is further modified by the occurrence of heterogeneous grazing patterns through time and space (Willms et al. 1988; O’Connor 1992; Bailey et al. 1996; McIvor et al. 2005), and heterogeneity often increases with increasing size of management units (Senft et al. 1985; Stuth 1991; Bailey et al. 1996). Preferential use of specific patches results in uneven animal distribution, which increases the stocking rate on preferred patches compared to the entire management unit (Fuhlendorf and Engle 2001, 2004). Animal selection is minimally affected by small-scale heterogeneity at the feeding station level, but it is profoundly affected by large-scale heterogeneity at the landscape level; therefore, both the size and spatial arrangement of grazed patches are major components of selective grazing (Wallis de Vries and Schippers 1994; Wallis de Vries et al. 1999). Grazing patterns within landscapes are strongly influenced by the spatial distribution of topography, water, cover, minerals, and inter- and intraspecific animal interactions (Coughenour 1991). In time, heterogeneous use of rangelands may alter the spatial and temporal variability of primary production, and it may intensify localized herbivore impacts (Fuls 1992; Kellner and Bosch 1992; Illius and O'Connor 1999). A shifting mosaic of intensively grazed and underutilized patches may be critical to the maintenance of structural heterogeneity and biological diversity of rangeland ecosystems (Fuhlendorf et al. 2006).

The fundamental question is this: Do these unified principles of vegetation response to grazing determine that rotational grazing is superior to continuous grazing? If not, why not? Answers to these questions will provide a greater understanding 
of the perceptions and assumptions underlying continued support for rotational grazing.

\section{RESULTS OF EXPERIMENTAL GRAZING RESEARCH}

Comparisons of continuous, season-long grazing and rotational grazing have been conducted in numerous rangeland ecosystems worldwide, but the vast majority have originated in the United States and South Africa. Sampson (1951) and Heady (1961) provided evaluations of the initial grazing experiments and reported little or no advantage of rotational over continuous grazing for either vegetation or animal response variables (Table 2). We have undertaken a comprehensive assessment of the two most frequently quantified variables, plant production or standing crop biomass and animal production, expressed on both a per head and per unit area basis. Comparisons of published reports among grazing systems must be done with caution because stocking rates were often confounded by the unwarranted recommendation that rotational grazing could sustainably increase stocking rate by 1.5-2 times compared to continuous grazing (Savory and Parsons 1980; Savory 1988). These variables were evaluated from published investigations comparing continuous and rotational grazing derived from the AGRICOLA database (http://agricola.nal.usda.gov), the grazing systems information in Holechek et al. (2001, Tables 9.1 and 9.2), and the archived articles of the Journal of Range Management (http:// uvalde.tamu.edu/jrm/jrmhome.htm; Appendix I). Information was also reported for geographic location, ecosystem type, relative stocking rate, and number and size of pastures for each of the respective investigations. Only those investigations published in the peer-reviewed literature were utilized to ensure data quality and to enhance transparency of the data set. Variables were indicated to differ between continuous and rotational grazing only when they were reported as being statistically significant by the authors. For each experiment, plant and/or animal production was characterized as 1) greater for continuous grazing $(C G>R G), 2)$ greater for rotational grazing ( $R G>C G)$, or 3 ) equal if differences did not exist between continuous and rotational grazing $(\mathrm{CG}=\mathrm{RG})$. These comparative responses were summarized and presented as separate histograms for those investigations that used similar stocking rates between grazing treatments (Fig. 1A), those that used greater stocking rates for rotational than continuous grazing (Fig. 1B), and for all stocking rates combined (Fig. 1C).

Eighty-nine percent of the experiments (17 of 19) reported no differences for plant production/standing crop between rotational and continuous grazing with similar stocking rates (Fig. 1A). When stocking rate was less for continuous than rotational grazing, $75 \%$ of the experiments (3 of 4 ) reported either no differences or greater plant production for continuous grazing (Fig. 1B). Across all stocking rates, $83 \%$ of the experiments (19 of 23) reported no differences for plant production between rotational and continuous grazing, 13\% (3) reported greater plant production for rotational compared to continuous grazing, and one experiment $(4 \%)$ reported greater production for continuous grazing (Fig. 1C).

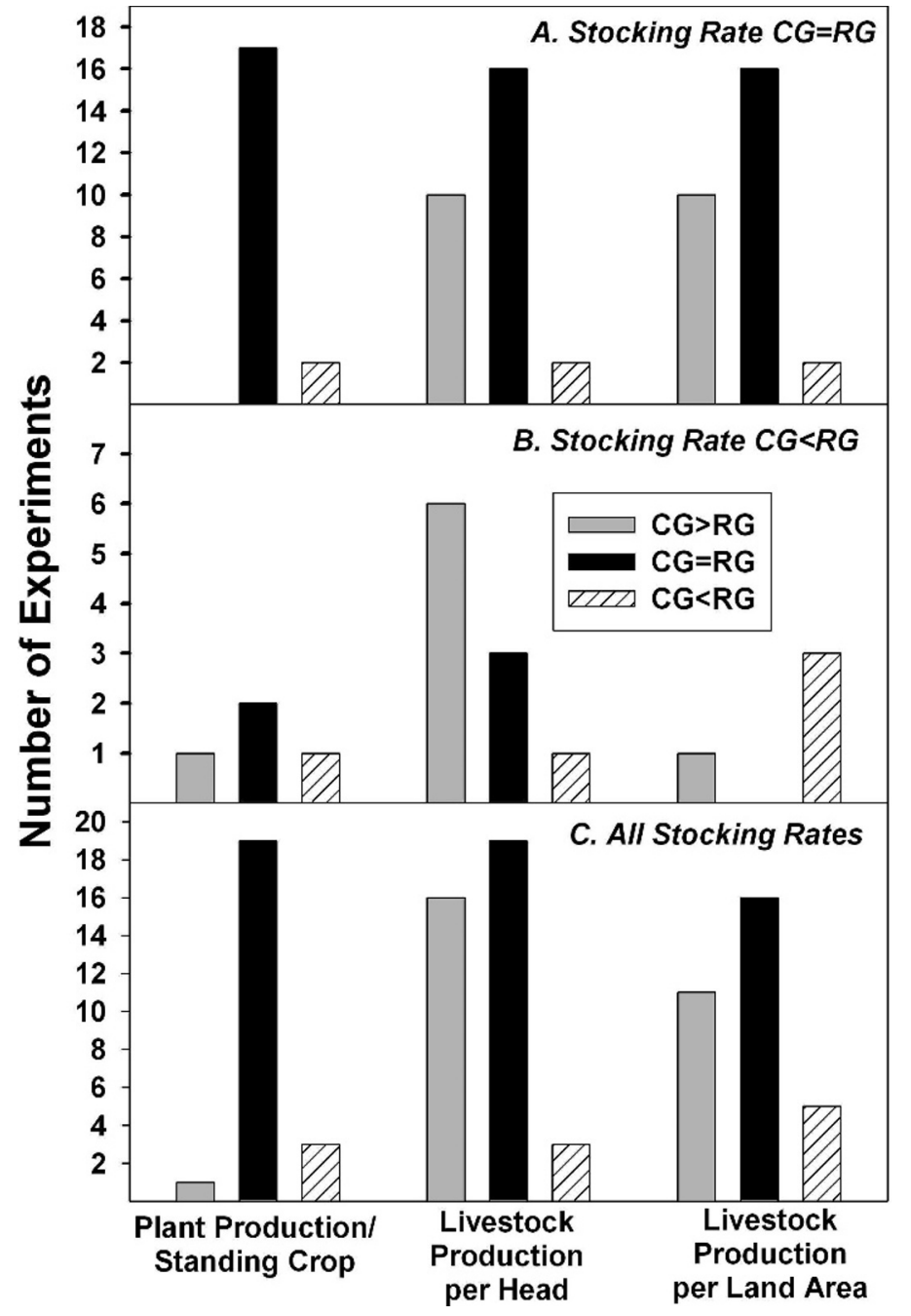

Figure 1. Number of published grazing experiments that reported significantly higher, equal, or lower plant and animal production responses for continuous compared to rotational grazing at $(\mathbf{A})$ similar stocking rates, (B) higher stocking rates for rotational grazing, and (C) across stocking rates for all experiments. Animal production is presented as both a per head and per land area response. Citations and other relevant information for the experiments comprising these data are presented in Appendix I.

Fifty-seven percent of the experiments (16 of 28) reported no differences for animal production per head between rotational and continuous grazing with similar stocking rates, and $36 \%$ (10) reported greater per head production for continuous grazing (Fig. 1A). When stocking rate was less for continuous than rotational grazing, $90 \%$ of the experiments (9 of 10) reported either similar or greater per head animal production for continuous grazing (Fig. 1B). Across all stocking rates, 50\% (19 of 38) of the experiments reported no differences for animal production per head between rotational and continuous grazing, $8 \%$ (3) reported greater production for rotational grazing, and $42 \%$ (16) reported greater production for continuous grazing (Fig. 1C).

Fifty-seven percent of the experiments (16 of 28) reported no differences for animal production per unit land area between rotational and continuous grazing with similar stocking rates, and $36 \%$ (10) reported advantages for continuous grazing 
(Fig. 1A). When stocking rate was less for continuous than rotational grazing, $75 \%$ (3 of 4 ) of the experiments reported greater animal production per area for rotational grazing (Fig. 1B). Across all stocking rates, $50 \%$ (16 of 32 ) of the experiments reported no differences for animal production per land area between rotational and continuous grazing, 16\% (5) reported greater production for rotational grazing, and $34 \%$ (11) reported greater production for continuous grazing (Fig. 1C).

These experimental results conclusively demonstrate that rotational grazing is not superior to continuous grazing across numerous rangeland ecosystems (Appendix I), and they are consistent with those of previous reviews (Table 2). These results further corroborate the long-standing conclusions that stocking rate and weather variation account for the majority of variability associated with plant and animal production on rangelands (Van Poollen and Lacey 1979; Heitschmidt and Taylor 1991; Gillen et al. 1998; Holechek et al. 2001; Derner and Hart 2007).

\section{WHY IS ROTATIONAL GRAZING NOT SUP- PORTED BY EXPERIMENTAL DATA?}

Rotational grazing systems are specifically designed to redistribute grazing pressure (i.e., forage availability/forage demand) in time and space for any given stocking rate (i.e., animal number/land area/time; Heitschmidt and Taylor 1991) to provide greater managerial control over the frequency, intensity, and uniformity of plant defoliation by modifying the length of grazing period (e.g., Gillen et al. 1990; Derner et al. 1994). Why does the redistribution of grazing pressure, which translates to periodic rest or deferment among pastures, not have a more beneficial effect on plant production? Two broad responses to this question are summarized below. These responses are not mutually exclusive, and no single response is anticipated to provide a complete explanation.

\section{Presumed Benefits of Rotational Grazing Were Overextended}

The absence of observed benefits of rotational over continuous grazing in experimental research indicates that many of the anticipated benefits of rotational systems have not been realized (O'Reagain and Turner 1992). For example, experimental evidence indicates that defoliation is not always controlled more effectively in rotational grazing systems than in continuous grazing (Gammon and Roberts 1978a, 1978b, 1978c; Hart et al. 1993b) and that forage quality and quantity are not consistently and substantially increased in intensive systems compared to continuous grazing (Denny and Barnes 1977; Walker et al. 1989; Holechek et al. 2000). This further substantiates the notion that rotational grazing may have been introduced with heightened and unrealistic expectations that were not founded on evidence-based recommendations (e.g., Heady 1961).

Expectations of grazing systems may have been inadvertently heightened by the critical need to promote the sustainable use and recovery of rangelands damaged by excessive grazing early in the 20th century (Smith 1896; Sampson 1951; Hart and Norton 1988). The critical interpretation of continuous grazing, prompted by excessive stocking rates that were

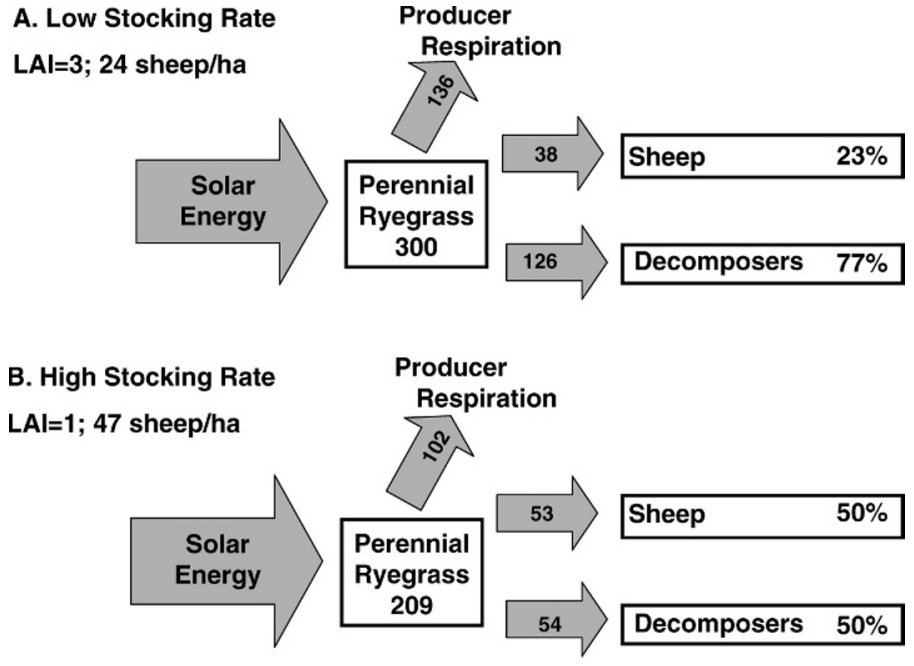

Figure 2. Illustration of the consequences of $(\mathbf{A})$ low and (B) high stocking rate on energy partitioning $\left(\mathrm{kg} \mathrm{C} \cdot \mathrm{ha}^{-1} \cdot \mathrm{d}^{-1}\right)$ between plant production and forage utilization by livestock in grazed ecosystems. Leaf area index (LAl) and forage utilization are interrelated so that neither can be optimized independently; rather, both must be simultaneously optimized to sustain plant and animal production. This fundamental requirement to balance plant growth and forage consumption by livestock partially explains why grazing research has found stocking rate to affect plant and animal response variables to a greater extent than grazing system on rangelands (redrawn from Parsons et al. 1983).

common prior to the implementation of proper grazing management, may still be promulgated today. The high stocking rates common to the late 19th and early 20th centuries were unsustainable, and the negative consequences of those high stocking rates should not be interpreted as a condemnation of continuous grazing at appropriate stocking rates (e.g., Ash and Stafford Smith 1996; Gillen and Sims 2006; Jacobo et al. 2006).

\section{Ecological Constraints Occur in All Grazed Ecosystems}

A fundamental ecological explanation for why the unifying principles of vegetation responses to grazing do not support greater effectiveness of rotational grazing is that grazing management must optimize several competing ecological processes to attain production goals sustainably. Grazing management must optimize both residual leaf area to maintain plant productivity and forage utilization to yield sufficient animal nutrition and production on an area basis (Parsons et al. 1983; Briske and Heitschmidt 1991). This fundamental management dilemma places similar constraints on all grazed ecosystems and limits the potential benefits derived from the spatial and temporal redistribution of grazing pressure for any given stocking rate.

Low stocking rates or grazing pressures promote plant production by maintaining high leaf area per unit land area. However, a relatively small proportion of this production is harvested by livestock, and the majority senesces and decomposes without being consumed (Fig. 2). This will effectively promote conservation goals over short-term economic profitability, which may be a viable management alternative on some rangelands. Higher stocking rates reduce plant production by 

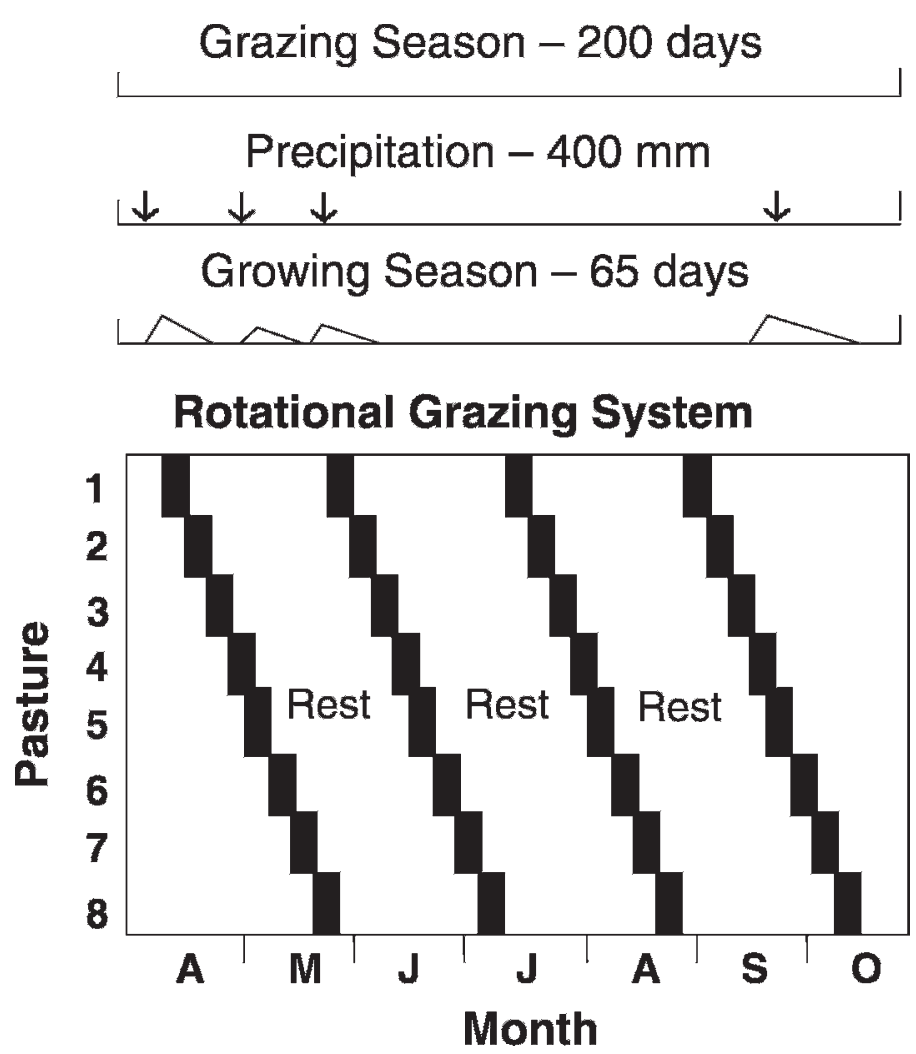

Figure 3. Depiction of how infrequent and unpredictable rainfall and corresponding periods of plant growth can minimize the benefits of rest on vegetation responses in rotational grazing systems. Rest periods that coincide with limited plant growth convey minimal benefit to plants so that the impacts of increased grazing pressure during short grazing periods may not be offset during subsequent rest periods. This represents the most plausible ecological explanation for why grazing research has found the redistribution of grazing pressure to be of minimal benefit to vegetation compared to continuous grazing on rangelands.

decreasing leaf area per unit ground area, but both the percentage and absolute amount of plant production harvested by livestock increases. Extremely high stocking rates are associated with very high forage utilization, but plant production is reduced so severely that even these high rates of utilization do not provide sufficient forage and animal production declines. In addition to suppressed plant and animal production, excessive stocking rates are often unsustainable from the perspective of desired plant species composition, soil stability, and hydrological function (Thurow 1991; Milton et al. 1994).

The ability to optimize plant production and forage harvest takes on even greater complexity on rangelands because the periodicity and predictability of plant growth are constrained by limited and erratic precipitation. As aridity increases and the duration and predictability of plant growth decreases, the potential benefit derived from the redistribution of grazing pressure in space and time becomes less important (Taylor et al. 1993; Holechek et al. 2001; Ward et al. 2004). Consider a situation in which the grazing season is 200 days, but the cumulative period of plant growth, scattered over several periods of various duration (i.e., primarily early and late in the season), is only 65 days (Fig. 3). Stocking rate must be adjusted, regardless of grazing system, to maintain sufficient forage to carry livestock through periods of minimal plant growth. In addition, rest and deferment during periods of minimal plant growth, associated with low soil water availability or temperature extremes, limit the potential for positive vegetation responses (Heitschmidt et al. 2005; Gillen and Sims 2006). Conditions of limited and erratic precipitation and productivity are the rule, rather than the exception, on most rangelands throughout the world. This interpretation indicates why the redistribution of grazing pressure conveys only a minor contribution to plant and animal production in grazed ecosystems compared to the variables of weather and stocking rate (e.g., O'Reagain and Turner 1992; Ash and Stafford Smith 1996; Gillen and Sims 2006).

The ecological dynamics and managerial challenges characteristic of most rangelands are very different from those associated with high and consistent plant production of mesic pasture systems, in which the principles of rotational grazing were initially devised (e.g., Voisin 1959; Heady 1970; Robson 1973; Woledge 1978). An overestimation of the presumed benefits of rest from grazing, within the framework of rotational grazing systems (e.g., several weeks rest between brief and often intensive grazing periods), may represent the primary misconception underlying continued advocacy for rotational grazing on rangelands (e.g., Taylor et al. 1993; Holechek et al. 2001; Gillen and Sims 2006). We fully appreciate that longer-term rest and reduced stocking, especially during conditions favorable to plant growth, contribute to the sustainability and recovery of grazed ecosystems (e.g., Holechek et al. 1999; Müller et al. 2007).

\section{PERCEPTIONS FOR CONTINUED ADVOCACY OF ROTATIONAL GRAZING}

In spite of the experimental evidence documenting that rotational grazing is not superior to continuous grazing on rangelands, rotational grazing continues to be promoted and implemented (Norton 1998, 2003; Tainton et al. 1999; Teague et al. 2004). However, it is uncertain where the purported benefits of rotational grazing arise because vegetation monitoring is seldom done, and records of animal performance, cash flow, and capital inputs are seldom reported for ranch enterprises (Heady 1961, 1970). Three broad arguments frequently invoked to support advocacy for rotational grazing are evaluated below.

\section{Context of Experimental Research}

Grazing research has not adequately assessed the effects of grazing at large scales (Fuls 1992; O’Connor 1992; Bailey et al. 1996; Archibald et al. 2005), which often demonstrates the occurrence of patch- and area-specific grazing. Smaller experimental pastures usually result in more uniform distribution of grazing pressure, which may not appropriately describe how domestic grazing animals utilize large landscapes or, in the case of native ungulates, how they migrate regionally. Teague and others (Teague and Dowhower 2003; Teague et al. 2004) demonstrated that rest periods associated with rotational grazing facilitated an improvement in plant species composition of frequently grazed patches relative to continuously 
grazed areas at the same stocking rate in large management units (1500-2000 ha). The direct application of research results obtained in small-scale experiments $(<200$ ha; Appendix I) to large ranch enterprises may not be entirely appropriate because the ecological processes of interest often do not scale in a linear fashion (Fuhlendorf and Smeins 1999). Evidence documenting the occurrence of beneficial grazing system effects at large scales, in the absence of comparable responses at smaller scales, has not been rigorously evaluated.

Failure to consider the time required for ecosystems to adjust to changes in management regimes may potentially mask ecosystem responses to the implementation of grazing systems. Several years may be required for some variables to adjust and show a response to the new management regime (Provenza 2003). Research experiments that operate for short periods following treatment imposition may largely capture the period of system adaptation and underestimate the long-term potential of grazing systems. However, several well-designed comparisons of rotational and continuous grazing have been conducted for 8-25 years without documenting a substantial change in the trajectory of plant and animal response variables (Hart et al. 1993a, 1993b; Derner et al. 1994; Manley et al. 1997; Gillen et al. 1998; McCollum and Gillen 1998; Derner and Hart 2007).

Experimental grazing research embodies a fundamental tradeoff between a robust assessment of ecological processes and the ability to mimic the responses associated with adaptive management. Research protocol requires that grazing experiments be structured in a manner that minimizes both ecological and managerial variability to effectively test hypotheses that enhance our understanding of critical ecological processes operating in grazed ecosystems. These research requirements do not allow grazing experiments to necessarily mimic management activities targeting production or conservation goals at the ranch enterprise (Heady 1970). Grazing treatments are often applied on a more rigid schedule to ensure experimental integrity and repeatability compared to commercial systems that are adaptively managed. Jacobo and others (2006) have partially documented the importance of adaptive management to grazing system effectiveness in ranch-scale comparisons of rotational and continuous grazing in the flooding pampas of Argentina.

\section{Conservation Goals}

Rangeland ecosystems are capturing greater public attention with growing recognition of the variety of products and services they provide (Havstad et al. 2007). These ecosystems are increasingly recognized as sources of water, biodiversity, recreation, aesthetics, wildlife habitat, carbon sequestration, and residential sites, in addition to livestock products. Conservation goals often emerge at large scales, and even though the flexibility associated with rotational grazing systems can provide managers with opportunities to manipulate grazing frequency, intensity, and seasonality to pursue specific conservation goals (e.g., bird nesting success, periodic plant establishment or reproduction, fuel accumulation or suppression), there has not yet been a comprehensive accounting of the conservation effects associated with the large-scale adoption of grazing systems. The majority of grazing experiments have not collected the appropriate variables, at the appropriate scale, to evaluate environmental quality and conservation issues (but see Hickman et al. 2004).

The response of soil hydrological characteristics represents an important exception to this generalization based on a substantial number of experimental investigations conducted in the 1970s and 1980s. The response of soil hydrological characteristics to grazing largely parallels those of other ecological variables in that stocking rate is the most important driver, irrespective of grazing system (Wood and Blackburn 1981; Thurow 1991). This occurs because the removal of large amounts of plant cover and biomass by intensive grazing reduces the potential to dissipate the energy of raindrop impact and overland flow. The erosive energy of water and the longterm reduction of organic matter additions to the soil detrimentally affect numerous soil properties, including increased bulk density, disruption of biotic crusts, reduced aggregate stability, and organic matter content, to reduce infiltration rate and increase sediment yield and runoff. Animal trampling is another source of mechanical energy that breaks soil aggregates and is therefore negatively correlated with maintenance of soil structure necessary for high infiltration rates (Warren et al. 1986; Thurow 1991; Holechek et al. 2000). These results refute prior claims that animal trampling associated with high stocking rates or grazing pressures in rotational grazing systems enhance soil properties and promote hydrological function (Savory and Parsons 1980; Savory 1988). However, soil properties and hydrological processes do appear to recover with prolonged grazing deferment following intensive grazing, and rotational grazing may maintain higher infiltration rates than continuous grazing at high stocking rates (Thurow et al. 1988; Thurow 1991). These hydrological responses to grazing are strongly contingent on community composition, with communities that provide greater cover and obstruction to overland flow such as midgrass-dominated communities having greater hydrological function, including infiltration rate, than short grass-dominated communities (Wood and Blackburn 1981; Thurow 1991). Grazing management appears to have the greatest potential to enhance hydrological function by facilitating improvement in herbaceous species composition of grazed ecosystems.

\section{Involvement of Human Dimensions}

This synthesis poses the hypothesis that the interface between human dimensions and grazing systems represents a major source of inconsistent interpretations regarding the potential benefits of grazing systems. This long-standing controversy very likely originates from managerial emphasis on the socioeconomic benefits of the ranch enterprise while research scientists focus on ecological processes associated with vegetation-soil-herbivore interactions of individual management units. It is not unexpected that inconsistent interpretations would result from the assessment of distinct goals, with different procedures, by groups with divergent perspectives. Management goals, abilities, and opportunities as well as personal goals and values (e.g., human dimensions) are inextricably integrated within grazing systems, and they are likely to interact with the adoption and operation of grazing systems to an equal or greater extent than the underlying ecological processes. 
Although circumstantial evidence from successful grazing managers cannot be elevated to the status of experimental data, valuable insight can be gained by comparing the experiences of successful managers with relevant research results regardless of grazing system. Research is required to document these "success stories" and to direct the development of a more robust approach to understanding and implementing successful grazing management. A novel case study approach was adopted by Jacobo et al. (2006), who compared adjacent ranches that had employed either continuous or rotational grazing to achieve the optimal production outcome. The strength of this approach is that it enables researchers to evaluate the entire ranch enterprise, including the capacity to manage adaptively for the best possible outcomes, within the constraints of the respective grazing regime. This approach simultaneously evaluates ecological and managerial responses, but it has yet to be determined whether or not it will be possible to distinguish between them. Simulation modeling represents an additional and complementary research approach where cost and logistics preclude field experimentation over large spatial and temporal scales (e.g., Hahn et al. 1999; Beukes et al. 2002; Diaz-Solis et al. 2003; Teague and Foy 2004). This approach is well suited to evaluate the managerial and ecological components of grazing management, both independently and in combination. The potential synergistic effects of well-managed rotational grazing systems have not been examined experimentally at the level of the ranch enterprise (but see Jacobo et al. 2006).

It is disconcerting to realize that little progress has been made in our understanding of management contributions to the performance of grazing systems since Heady (1961) made this insightful observation nearly a half-century ago. Advocates of rotational grazing often support their perceptions by indicating the experimental grazing research is incorrect, rather than by evaluating and quantifying the potential merits of effective management and planning decisions. A quantitative accounting of the potential managerial contributions to the success of rotational grazing systems is a prerequisite for complete resolution of this controversy.

\section{IMPLICATIONS AND PERCEPTION RECONCILIATION}

The rangeland profession has become mired in confusion, misinterpretation, and uncertainty with respect to the evaluation of grazing systems and the development of grazing recommendations and policy decisions. We contend that this has occurred because recommendations have traditionally been based on perception, personal experience, and anecdotal interpretations of management practices, rather than evidence-based assessments of ecosystem responses, which is a common phenomenon in ecosystem management (Pullin et al. 2003; Sutherland et al. 2004). This has seriously impeded the development of more robust, consistent, and unified grazing management recommendations and policy decisions to govern this predominant land use on rangelands.

This synthesis demonstrates that continued advocacy for rotational grazing as a superior system of grazing is founded on perception and anecdotal interpretations, rather than on the preponderance of experimental evidence. Rotational grazing as a means to increase vegetation and animal production has been subjected to as rigorous a testing regime as any hypothesis in the rangeland profession, and it has been found to convey few, if any, consistent benefits over continuous grazing. It is unlikely that researcher oversight or bias has contributed to this conclusion given the large number of grazing experiments, investigators, and geographic locations involved over a span of six decades. This synthesis establishes that the ecological relationships of grazing systems have been reasonably well resolved, at the scales investigated, and that a continuation of costly grazing experiments adhering to conventional research protocols will yield little additional information. Grazing research has demonstrated that a set of potentially effective grazing strategies exist, none of which have unique properties that set one apart from the other in terms of ecological effectiveness. This very likely occurs because the performance of all grazed ecosystems is constrained by similar sets of ecological variables, indicating that differences among them are dependent on the effectiveness of management models, rather than the occurrence of unique ecological phenomena.

The experimental evidence indicates that rotational grazing is a viable grazing strategy on rangelands, but the perception that it is superior to continuous grazing is not supported by the vast majority of experimental investigations. There is no consistent or overwhelming evidence demonstrating that rotational grazing simulates ecological processes to enhance plant and animal production compared to that of continuous grazing on rangelands. We recommend that these evidence-based conclusions be explicitly incorporated into management and policy decisions addressing the predominant land use on rangelands.

\section{ACKNOWLEDGMENTS}

We thank the associate editor, Emilio Laca, and four anonymous reviewers for their insightful contributions to this manuscript.

\section{LITERATURE CITED}

Anderson, V. J., And D. D. Briske. 1995. Herbivore-induced species replacement in grasslands: is it driven by herbivory tolerance or avoidance. Ecological Applications 5:1014-1024.

Archibald, S., W. J. Bond, W. D. Stock, and D. H. K. Fairbanks. 2005. Shaping the landscape: fire-grazer interactions in an African savanna. Ecological Applications 15:96-109.

Ash, A. J., and D. M. Stafford Smith. 1996. Evaluating stocking rate impacts in rangelands: animals don't practice what we preach. Rangelands Journal 18: 216-243.

Balley, D. W., J. E. Gross, E. A. Laca, L. R. Rittenhouse, M. B. Coughenour, D. M. Swift, And P. L. Sims. 1996. Mechanisms that result in large herbivore grazing patterns. Journal of Range Management 49:386-400.

BeLskY, A. J. 1986. Does herbivory benefit plants? A review of the evidence. American Naturalist 127:870-892.

Beukes, P. C., R. M. Cowling, and S. I. Higgins. 2002. An ecological economic simulation model of a non-selective grazing system in the Nama Karoo, South Africa. Ecological Economics 42:221-242.

Briske, D. D., and R. K. Heitschmidt. 1991. An ecological perspective. In: R. K. Heitschmidt and J. W. Stuth [EDS.]. Grazing management: an ecological perspective. Portland, OR, USA: Timber Press. p. 11-26.

BRISKE, D. D., AND J. H. RichaRds. 1995. Plant responses to defoliation: a morphological, physiological and demographic evaluation. In: D. J. Bedunah 
and R. E. Sosebee [EDS.]. Wildland plants: physiological ecology and developmental morphology. Denver, CO, USA: Society for Range Management. p. $635-710$.

Caldwell, M. M., J. H. Richards, D. A. Johnson, R. S. Nowak, and R. S. Dzurec. 1981. Coping with herbivory: photosynthetic capacity and resource allocation in two semiarid Agropyron bunchgrasses. Oecologia 50:14-24.

Coughenour, M. B. 1991. Spatial components of plant-herbivore interactions in pastoral, ranching, and native ungulate ecosystems. Journal of Range Management 44:530-542.

Denny, R. P., and D. L. Barnes. 1977. Trials of multi-paddock grazing systems on veld. III. A comparison of six grazing procedures at two stocking rates. Rhodesia Journal of Agricultural Research 15:129-143.

Derner, J. D., R. L. Gillen, F. T. McCollum, and K. W. Tate. 1994. Little bluestem tiller defoliation patterns under continuous and rotational grazing. Journal of Range Management 47:220-225.

Derner, J. D., and R. H. HaRt. 2007. Grazing-induced modifications to peak standing crop in northern mixed-grass prairie. Rangeland Ecology and Management 60:270-276.

Díaz, S., I. Noy-MeIR, and M. Cabido. 2001. Can grazing response of herbaceous plants be predicted from simple vegetative traits? Journal of Applied Ecology 38:497-508.

Díaz-Solis, H., M. M. Kothmann, W. T. Hamilton, and W. E. Grant. 2003. A simple ecological sustainability simulator (SESS) for stocking rate management on semi-arid grazinglands. Agricultural Systems 76:655-680.

DyksterhuIs, E. J. 1949. Condition and management of range land based on quantitative ecology. Journal of Range Management 2:104-115.

ELLIson, L. 1960. Influence of grazing on plant succession of rangelands. Botanical Review 26:1-78.

Frank, D. A., and S. J. McNaughton. 1993. Evidence for the promotion of aboveground grassland production by native large herbivores in Yellowstone National Park. Oecologia 96:157-161.

Funlendorf, S. D., AND D. M. Engle. 2001. Restoring heterogeneity on rangelands: ecosystem management based on evolutionary grazing patterns. Bioscience $51: 625-632$

Fuhlendorf, S. D., And D. M. Engle. 2004. Application of the fire-grazing interaction to restore a shifting mosaic on tallgrass prairie. Journal of Applied Ecology 41:604-614.

Fuhlendorf, S. D., W. C. Harrell, D. M. Engle, R. G. Hamilton, C. A. Davis, and D. M. Leslie, JR. 2006. Should heterogeneity be the basis for conservation? Grassland bird response to fire and grazing. Ecological Applications 16:1706-1716.

Funlendorf, S. D., And F. E. Smeins. 1999. Scaling effects of grazing in a semi-arid savanna. Journal of Vegetation Science 10:731-738.

FuLs, E. R. 1992. Semi-arid and arid rangelands: a resource under siege due to patch-selective grazing. Journal of Arid Environments 22:191-193.

Gammon, D. M., and B. R. Roberts. 1978a. Patterns of defoliation during continuous and rotational grazing of the Matopos Sandveld of Rhodesia. 1. Selectivity of grazing. Rhodesia Journal of Agricultural Research 16:117-131.

Gammon, D. M., And B. R. RoberTs. 1978b. Patterns of defoliation during continuous and rotational grazing of the Matopos Sandveld of Rhodesia. 2. Severity of defoliation. Rhodesia Journal of Agricultural Research 16:133-145.

Gammon, D. M., AND B. R. RoberTs. 1978c. Patterns of defoliation during continuous and rotational grazing of the Matopos Sandveld of Rhodesia. 3. Frequency of defoliation. Rhodesia Journal of Agricultural Research 16:147-164.

Georgiadis, N. J., and S. J. McNaughton. 1990. Elemental and fiber contents of savanna grasses: variation with grazing, soil type, season and species. Journal of Applied Ecology 27:623-634.

Gillen, R. L., F. T. McCollum, and J. E. Brummer. 1990. Tiller defoliation patterns under short duration grazing in tallgrass prairie. Journal of Range Management 43:95-99.

Gilleen, R. L., F. T. McCollum III., K. W. Tate, And M. E. Hodges. 1998. Tallgrass prairie response to grazing system and stocking rate. Journal of Range Management $51: 139-146$

Gillen, R. L., AND P. L. Sims. 2006. Stocking rate and weather impacts on sand sagebrush and grasses: a 20-year record. Rangeland Ecology and Management $59: 145-152$
Hahn, B. D., F. D. Richardson, and A. M. Starfield. 1999. Frame-based modeling as a method of simulating rangeland production systems in the long term. Agricultural Systems 62:29-49.

Hart, R. H., J. Bissio, M. J. Samuel, and J. W. Waggoner, JR. 1993a. Grazing systems, pasture size, and cattle grazing behavior, distribution and gains. Journal of Range Management 46:81-87.

HaRT, R. H., S. Clapp, and P. S. TeSt. 1993b. Grazing strategies, stocking rates, and frequency and intensity of grazing on western wheatgrass and blue grama. Journal of Range Management 46:122-126.

HART, R. H., AND B. E. NoRton. 1988. Grazing management and vegetation response. In: P. T. Tueller [ED.]. Vegetation science applications for rangeland analysis and management. Boston, MA, USA: Kluwer Academic Publishers. p. 493-525.

Havstad, K. M., D. P. C. Peters, R. Skaggs, J. Brown, B. Bestelmeyer, E. Fredrickson, J. HERRICK, AND J. WRIGHT. 2007. Ecological services to and from rangelands of the United States. Ecological Economics (in press).

Heady, H. F. 1961. Continuous vs. specialized grazing systems: a review and application to California annual type. Journal of Range Management 14:182193.

HeAdy, H. F. 1970. Grazing systems: terms and definitions. Journal of Range Management 23:59-61.

Heitschmidt, R. K., K. D. Klement, and M. R. Haferkamp. 2005. Interactive effects of drought and grazing on northern Great Plains rangelands. Rangeland Ecology and Management 58:11-19.

Heitschmidt, R. K., and C. A. TAYloR, JR. 1991. Livestock production. In: R. K. Heitschmidt and J. W. Stuth [EDS.]. Grazing management: an ecological perspective. Portland, OR, USA: Timber Press. p. 161-177.

Hickman, K. R., D. C. Hartnett, R. C. Cochran, and C. E. Owensby. 2004. Grazing management effects on plant species diversity in tallgrass prairie. Journal of Range Management 57:58-65.

Hodgkinson, K. C., And H. G. BASS BeCKING. 1977. Effect of defoliation on root growth of some arid zone perennial plants. Australian Journal of Agricultural Research 29:31-42.

Holechek, J. L., H. Gomez, F. Molinar, and D. Galt. 1999. Grazing studies: what have we learned. Rangelands 21:12-16.

Holechek, J. L., H. Gomez, F. Molinar, D. Galt, and R. Valdez. 2000. Short-duration grazing: the facts in 1999. Rangelands 22:18-22.

HolecheK, J. L., R. D. Pieper, and C. H. Herbel. 2001. Range management: principles and practices. 4th ed. Upper Saddle River, NJ, USA: Prentice Hall. 587 p.

HoRmaY, A. L., AND A. B. Evanko. 1958. Rest-rotation grazing: a management system for bunchgrass ranges. California, USA: USDA California Forest and Range Experiment Station Miscellaneous Paper 27.

Huston, J. E., and W. E. Pinchak. 1991. Range animal nutrition. In: R. K. Heitschmidt and J. W. Stuth [EDS.]. Grazing management: an ecological perspective. Portland, OR, USA: Timber Press. p. 27-63.

Illius, A. W., ANd T. G. O'Connor. 1999. On the relevance of non-equilibrium concepts to arid and semi-arid grazing systems. Ecological Applications 9:798-813.

Jacobo, E. J., A. M. Rodríguez, N. Bartoloni, and V. A. Deregibus. 2006. Rotational grazing effects on rangeland vegetation at a farm scale. Rangeland Ecology and Management 59:249-257.

Kellner, K., AND O. J. H. Bosch. 1992. Influence of patch formation in determining stocking rate for southern African grasslands. Journal of Arid Environments 22:99-105.

Manley, W. A., R. H. Hart, M. J. Samuel, M. A. Smith, J. W. Waggoner, JR., and J. T. Manley. 1997. Vegetation, cattle, and economic responses to grazing strategies and pressures. Journal of Range Management 50:638-646.

McCollum, F. T., III., AND R. L. GILlen. 1998. Grazing management affects nutrient intake by steers grazing tallgrass prairie. Journal of Range Management 51:69-72

McCollum, F. T., III., R. L. Gillen, B. R. Karges, and M. E. Hodges. 1999. Stocker cattle response to grazing management in tallgrass prairie. Journal of Range Management 52:120-126.

Mclvor, J. G., S. Mclntyre, I. Saeli, and J. J. Hodgkinson. 2005. Patch dynamics in grazed subtropical native pastures in south-east Queensland. Australian Ecology 30:445-464. 
McNaughton, S. J. 1979. Grazing as an optimization process: grass-ungulate relationships in the Serengeti. American Naturalist 113:691-703.

McNaughton, S. J. 1983. Compensatory plant growth as a response to herbivory. Oikos 40:329-336.

McNaughton, S. J. 1984. Grazing lawns: animals in herds, plant form, and coevolution. American Naturalist 124:863-886.

McNaughton, S. J. 1993. Grasses and grazers, science and management. Ecological Applications 3:17-20.

MerRILL, L. B. 1954. A variation of deferred rotation grazing for use under southwest range conditions. Journal of Range Management 7:152-154.

Milchunas, D. G., and W. K. Lauenroth. 1993. Quantitative effects of grazing on vegetation and soils over a global range of environments. Ecological Monographs 63:327-366.

Milton, S. J., W. R. J. Dean, M. A. du Plessis, and W. R. Siegfri. 1994. A conceptual model of arid rangeland degradation. Bioscience 44:70-76.

Müller, B., K. Frank, and C. Wissel. 2007. Relevance of rest periods in nonequilibrium rangeland systems-a modeling analysis. Agricultural Systems 92:295-317.

Norton, B. E. 1998. The application of grazing management to increase sustainable livestock production. Animal Production in Australia 22:15-26.

Norton, B. E. 2003. Spatial management of grazing to enhance both livestock production and resource condition: a scientific argument. In: N. Allsopp, A. R. Palmer, S. J. Milton, K. P. Kirkman, G. I. H. Kerley, C. R. Hurt, and C. J. Brown [EDs.]. Durban, South Africa: Proceedings of the VII International Rangeland Congress. p. 810-820.

O'Connor, T. G. 1992. Patterns of plant selection by grazing cattle in two savanna grasslands: a plant's eye view. Journal of the Grassland Society of Southern Africa 9:97-104.

O'Reagain, P. J., and J. R. Turner. 1992. An evaluation of the empirical basis for grazing management recommendations for rangeland in South Africa. Journal of the Grassland Society of South Africa 9:38-49.

Parsons, A. J., E. L. Leafe, B. Collett, P. D. Penning, and J. Lewis. 1983. The physiology of grass production under grazing. II. Photosynthesis, crop growth and animal intake of continuously grazed swards. Journal of Applied Ecology 20:127-139.

ProvenzA, F. D. 2003. Foraging behavior: managing to survive in a world of change. Utah Agricultural Experiment Station. Available at: http://behave.net/products/ booklet.html. Accessed 15 November 2007.

Pullin, A. S., T. M. Knight, D. A. Stone, and K. Charman. 2003. Do conservation managers use scientific evidence to support their decision-making? Biological Conservation 119:245-252.

Roвson, M. J. 1973. The growth and development of simulated swards of perennial ryegrass. 1. Leaf growth and dry weight change as related to the ceiling yield of a seeding sward. Annals of Botany 37:485-500.

Sampson, A. W. 1913. Range improvement by deferred and rotation grazing. USDA Bulletin 34

Sampson, A. W. 1919. Plant succession in relation to range management. USDA Bulletin 791.

Sampson, A. W. 1951. A symposium on rotation grazing in North America. Journal of Range Management 4:19-24.

SAvory, A. 1978. A holistic approach to ranch management using short duration grazing. In: D. N. Hyder [ED.]. Proceedings of the 1st International Rangeland Congress; 30-31 March 1984. Denver, C0, USA: Society for Range Management. p. 555-557.

SAvoRY, A. 1983. The Savory grazing method or holistic resource management. Rangelands 5:155-159.

SAvory, A. 1988. Holistic resource management. Covelo, CA, USA: Island Press. $564 \mathrm{p}$.

Savory, A., AND S. Parsons. 1980. The Savory grazing method. Rangelands 2:234237.

Senft, R. L., M. B. Coughenour, D. W. Balley, L. B. Rittenhouse, O. E. Sala, and D. M. SwIFt. 1987. Large herbivores' foraging and ecological hierarchies. Bioscience 37:789-799.
Smith, J. G. 1896. Forage conditions of the prairie region. In: USDA Yearbook of Agriculture-1895. Washington, DC, USA: USDA. p. 309-324.

Stuth, J. W. 1991. Foraging behavior. In: R. K. Heitschmidt and J. W. Stuth [eds.]. Grazing management: an ecological perspective. Portland, OR, USA: Timber Press. p. 65-83.

Sutherland, W. J., A. S. Pullin, P. M. Dolman, and T. M. Knight. 2004. The need for evidence-based conservation. Trends in Ecology and Evolution 19:305-308.

Tainton, N. M., A. J. Aucamp, and J. E. Danckwerts. 1999. Principles of managing veld. In: N. M. Tainton [ED.]. Veld management in South Africa. Pietermaritzburg, South Africa: University of Natal Press. p. 169-193.

Taylor, C. A., JR., T. D. Brooks, and N. E. Garza. 1993. Effects of short duration and high-intensity, low-frequency grazing systems on forage production and composition. Journal of Range Management 46:118-121.

Teague, W. R., and S. L. Dowhower. 2003. Patch dynamics under rotational and continuous grazing management in large, heterogeneous paddocks. Journal of Arid Environments 53:211-229.

Teague, W. R., S. L. Dowhower, and J. A. Waggoner. 2004. Drought and grazing patch dynamics under different grazing management. Journal of Arid Environments 58:97-117.

Teague, W. R., AND J. K. Foy. 2004. Can the SPUR rangeland simulation model enhance understanding of field experiments? Arid Land Research and Management 18:217-228.

Thurow, T. 1991. Hydrology and erosion. In: R. K. Heitschmidt and J. W. Stuth [EDS.]. Grazing management: an ecological perspective. Portland, OR, USA: Timber Press. p. 141-159.

Thurow, T. L., W. H. Blackburn, and C. A. Taylor, JR. 1988. Infilltration and interrill erosion responses to selected livestock grazing strategies, Edwards Plateau, Texas. Journal of Range Management 41:296-302.

Vallentine, K. A. 1967. Seasonal suitability, a grazing system for ranges of diverse vegetation types and condition classes. Journal of Range Management 20:395-397.

Van Poollen, H. W., And J. R. LACEY. 1979. Herbage response to grazing systems and stocking intensities. Journal of Range Management 32:250-253.

VAN SoESt, P. J. 1982. Nutritional ecology of the ruminant. Corvallis, OR, USA: O\&B Books. 375 p.

Vicari, M., and D. R. Bazely. 1993. Do grasses fight back? The case of anitherbivore defences. Trends in Ecology and Evolution 8:137-141.

VoIsIn, A. 1959. Grass productivity. New York, NY, USA: Philosophical Library. $353 \mathrm{p}$.

Walker, J. W., R. K. Heitschmidt, E. A. de Moraes, M. W. Kothmann, and S. L. Dowhower. 1989. Quality and botanical composition of cattle diets under rotational and continuous grazing treatments. Journal of Range Management 42:239-242.

Wallis de Vries, M. F., E. A. Laca, and M. W. Demment. 1999. The importance of scale of patchiness for selectivity in grazing herbivores. Oecologia 121:355363.

Wallis de VRIeS, M. F., and P. Schippers. 1994. Foraging in a landscape mosaic: selection for energy and minerals in free-ranging cattle. Oecologia 100:107-117.

Ward, D., D. Saltz, and B. T. NgalRorue. 2004. Spatio-temporal rainfall variation and stock management in arid Namibia. Journal of Range Management 57:130-140.

Warren, S. D., T. L. Thurow, W. H. Blackburn, and N. E. Garza. 1986. The influence of livestock trampling under intensive rotation grazing on soil hydrologic characteristics. Journal of Range Management 39:491-495.

Willms, W. D., J. F. Dormaar, and G. B. Schaalde. 1988. Stability of grazed patches on rough fescues grasslands. Journal of Range Management 41:503-508.

WoLEDGE, J. 1978. The effect of shading during vegetative and reproductive growth on the photosynthetic capacity of leaves in a grass sward. Annals of Botany 42:1085-1089.

Wood, M. K., AND W. H. BlackBURN. 1981. Grazing systems: their influence on infiltration rates in the rolling plains of Texas. Journal of Range Management 34:331-335. 


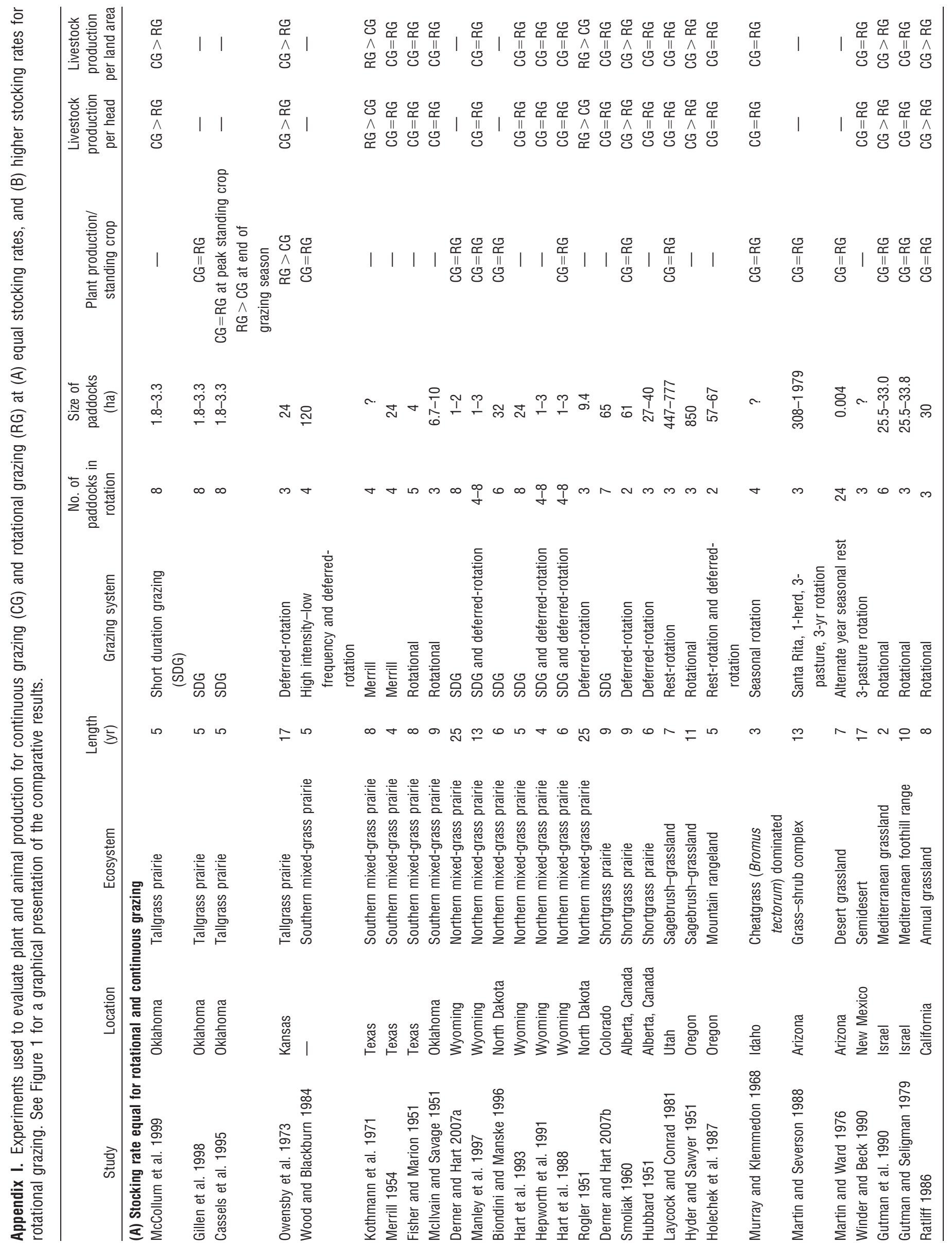




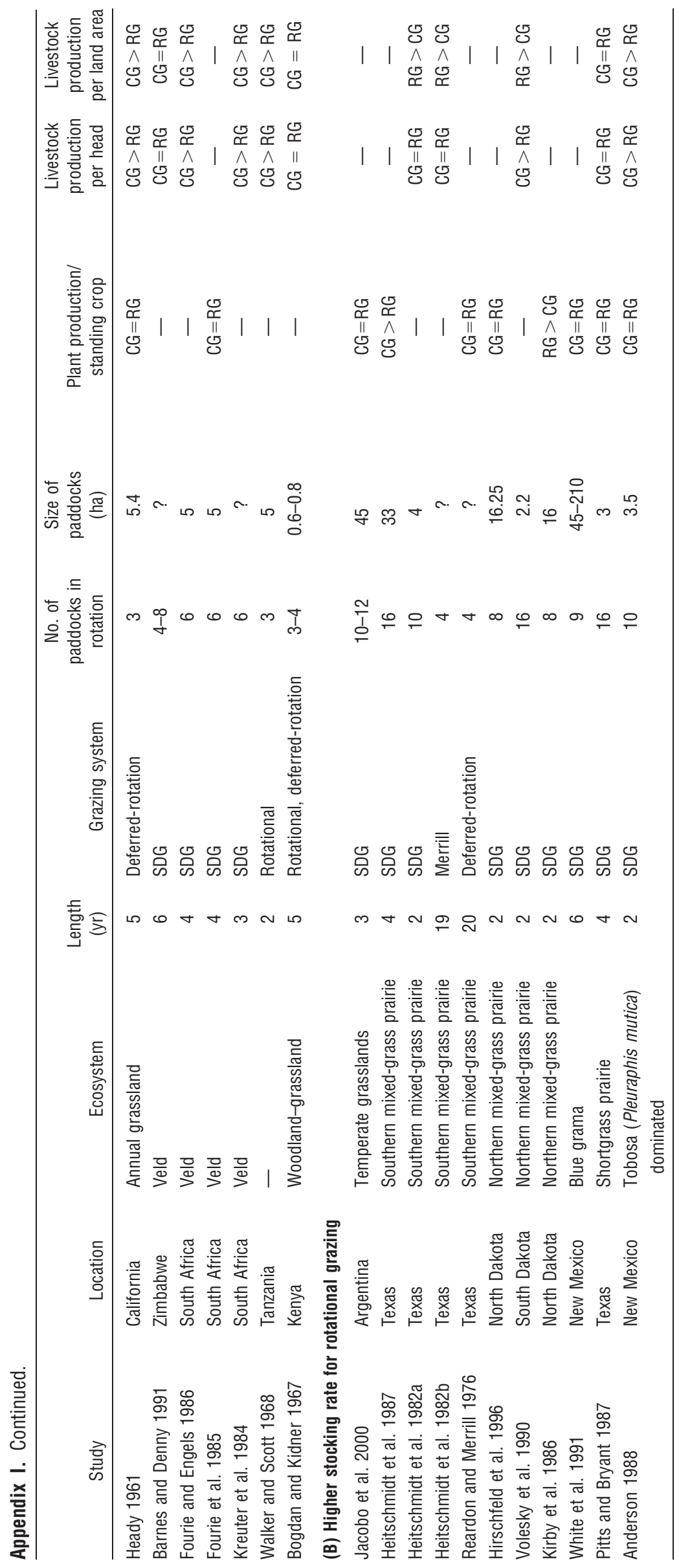




\section{APPENDIX II. LITERATURE CITED IN THE CONSTRUCTION OF APPENDIX I.}

Anderson, D. M. 1988. Seasonal stocking of tobosa managed under continuous and rotation grazing. Journal of Range Management 41:78-83.

Barnes, D. L., and R. P. Denny. 1991. A comparison of continuous and rotational grazing on veld at two stocking rates. Journal of Society of South African Grassland 8:168-173.

Biondini, M. E., And L. L. Manske. 1996. Grazing frequency and ecosystem processes in a northern mixed prairie, USA. Ecological Applications 5:239-256.

Bogdan, A. V., And E. M. Kidner. 1967. Grazing natural grassland in western Kenya. East African Agricultural and Forestry Journal 33:31-34.

Cassels, D. M., R. L. Gillen, F. T. McCollum, K. W. Tate, and M. E. Hodges. 1995. Effects of grazing management on standing crop dynamics in tallgrass prairie. Journal of Range Management 48:81-84.

Derner, J. D., and R. H. HaRt. 2007a. Grazing-induced modifications to peak standing crop in northern mixed-grass prairie. Rangeland Ecology and Management 60:20-276.

DeRneR, J. D., AND R. H. HART. 2007b. Livestock and vegetation responses to rotational grazing in shortgrass steppe. Western North American Naturalist 67:359-367.

Fisher, C. E., and P. T. Marion. 1951. Continuous and rotation grazing on buffalo and tobosa grassland. Journal of Range Management 4:48-51.

Fourie, J. H., AND E. A. N. Engels. 1986. Herbage intake by cattle on Tarchonanthus veld in the northern Cape as affected by stocking rate and grazing system. Journal of the Grassland Society of Southern Africa 3:85-89.

Fourie, J. H., D. P. J. Opperman, And B. R. Roberts. 1985. Influence of stocking rate and grazing systems on available grazing in the northern Cape. Journal of the Grassland Society of Southern Africa 2:24-26.

Gillen, R. L., F. T. McCollum, III, K. W. Tate, and M. E. Hodges. 1998. Tallgrass prairie response to grazing system and stocking rate. Journal of Range Management 51:139-146.

Gutman, M., and N. G. Seligman. 1979. Grazing management of Mediterranean foothill range in the upper Jordan River Valley. Journal of Range Management 32:86-92.

Gutman, M., N. G. Seligman, and I. Noy-Meir. 1990. Herbage production of Mediterranean grassland under seasonal and yearlong grazing systems. Journal of Range Management 43:64-68.

Hart, R. H., J. Bissio, M. J. Samuel, and J. W. Waggoner, JR. 1993. Grazing systems, pasture size, and cattle grazing behavior, distribution and gains. Journal of Range Management 46:81-87.

Hart, R. H., M. J. Samuel, P. S. Test, and M. A. Smith. 1988. Cattle, vegetation, and economic responses to grazing systems and grazing pressure. Journal of Range Management 41:282-286.

Heady, H. F. 1961. Continuous vs. specialized grazing systems: a review and application to the California annual type. Journal of Range Management 14:182-193

Heitschmidt, R. K., S. L. Dowhower, and J. W. Walker. 1987. Some effects of a rotational grazing treatment on quantity and quality of available forage and amount of ground litter. Journal of Range Management 40:318-321.

Heitschmidt, R. K., J. R. Frasure, D. L. Price, and L. R. Rittenhouse. 1982a. Short duration grazing at the Texas Experimental Ranch: weight gains of growing heifers. Journal of Range Management 35:375-379.

Heitschmidt, R. K., M. M. Kothmann, and W. J. Rawlins. 1982b. Cow-calf response to stocking rates, grazing systems, and winter supplementation at the Texas Experimental Ranch. Journal of Range Management 35:204-210.

Hepworth, K. W., P. S. Test, R. H. Hart, J. W. Waggoner, JR., and M. A. Smith. 1991. Grazing systems, stocking rates, and cattle behavior in southeastern Wyoming. Journal of Range Management 44:259-262.

Hirschfeld, D. J., D. R. Kirby, J. S. Caton, S. S. Silcox, and K. C. Olson. 1996. Influence of grazing management on intake and composition of cattle diets. Journal of Range Management 49:257-263.

Holechek, J. L., T. J. BerRy, and M. Vavra. 1987. Grazing system influences on cattle performance on mountain range. Journal of Range Management 40:55-59.
HubBard, W. A. 1951. Rotational grazing studies in western Canada. Journal of Range Management 4:25-29.

HydeR, D. N., AND W. A. SaWyer. 1951. Rotation-deferred grazing as compared to season-long grazing on sagebrush-bunchgrass ranges in Oregon. Journal of Range Management 4:30-34.

Jacobo, E. J., A. M. Rodriguez, J. L. Rossi, L. P. Salgado, and V. A. Deregibus. 2000. Rotational stocking and production of Italian ryegrass on Argentinean rangelands. Journal of Range Management 53:483-488.

KIRBY, D. R., M. F. Pessin, ANd G. K. Clambey. 1986. Disappearance of forage under short duration and season-long grazing. Journal of Range Management 39:496-500.

Kothmann, M. M., G. W. Mathis, and W. J. Waldrip. 1971. Cow-calf response to stocking rates and grazing systems on native range. Journal of Range Management 24:100-105.

Kreuter, U. P., G. M. Brockett, A. D. Lyle, N. M. Tainton, and D. I. Bransby. 1984. Evaluation of veld potential in east Griqualand using beef cattle under two grazing management systems. Journal of the Grassland Society of Southern Africa 1:5-10.

Larcock, W. A., and P. W. ConRad. 1981. Responses of vegetation and cattle to various systems of grazing on seeded and native mountain rangelands in Eastern Utah. Journal of Range Management 34:52-58.

Manley, W. A., R. H. Hart, M. J. Samuel, M. A. Smith, J. W. Waggoner, JR., and J. T. Manley. 1997. Vegetation, cattle, and economic responses to grazing strategies and pressures. Journal of Range Management 50:638-646.

Martin, S. C., and K. E. Severson. 1988. Vegetation response to the Santa Rita grazing system. Journal of Range Management 41:291-295.

Martin, S. C., and D. E. Ward. 1976. Perennial grasses respond inconsistently to alternate year seasonal rest. Journal of Range Management 29:346.

McCollum, F. T., III, R. L. Gillen, B. R. Karges, and M. E. Hodges. 1999. Stocker cattle response to grazing management in tallgrass prairie. Journal of Range Management 52:120-126.

Mcllvain, E. H., and D. A. Savage. 1951. Eight-year comparisons of continuous and rotational grazing on the Southern Plains Experimental Range. Journal of Range Management 4:42-47.

MerRILL, L. B. 1954. A variation of deferred rotation grazing for use under southwest range conditions. Journal of Range Management 7:152-154.

MurRaY, R. B., AND J. O. KLemmedson. 1968. Cheatgrass range in southern Idaho: seasonal cattle gains and grazing capacities. Journal of Range Management 21:308-313.

Owensby, C. E., E. F. Smith, and K. L. Anderson. 1973. Deferred-rotation grazing with steers in the Kansas Flint Hills. Journal of Range Management 26:393-395

Pitts, J. S., and F. C. Bryant. 1987. Steer and vegetation response to short duration and continuous grazing. Journal of Range Management 40:386-389.

RatLiff, R. D. 1986. Cattle responses to continuous and seasonal grazing of California annual grassland. Journal of Range Management 39:482-485.

Reardon, P. O., and L. B. Merrill. 1976. Vegetation response under various grazing management systems in the Edwards Plateau of Texas. Journal of Range Management 29:195-198.

RogleR, G. A. 1951. A twenty-five year comparison of continuous and rotation grazing in the northern plains. Journal of Range Management 4:35-41.

SMoLIAK, S. 1960. Effects of deferred-rotation and continuous grazing on yearling steer gains and shortgrass prairie vegetation of southeastern Alberta. Journal of Range Management 3:239-243.

Volesky, J. D., J. K. LeWIS, And C. H. ButTerfield. 1990. High-performance shortduration and repeated-seasonal grazing systems: effect on diets and performance of calves and lambs. Journal of Range Management 43:310315.

Walker, B., AND G. D. ScotT. 1968. Grazing experiments at Ukiriguru, Tanzania. I. Comparisons of rotational and continuous grazing systems on natural pastures of hardpan soils. East African Agricultural and Forestry Journal 34:224-255

White, M. R., R. D. Pieper, G. B. Donart, and L. W. Trifaro. 1991. Vegetational response to short-duration and continuous grazing in southcentral New Mexico. Journal of Range Management 44:399-403. 
Winder, J. A., And R. F. BeCk. 1990. Utilization of linear prediction procedures to evaluate animal response to grazing systems. Journal of Range Management 43:396-400.
Wood, M. K., and W. H. BlackBurn. 1984. Vegetation and soil responses to cattle grazing systems in the Texas rolling plains. Journal of Range Management 37:303-308. 